\title{
One Brotherhood in Aotearoa New Zealand: Protest, Resistance and Pacific Reggae
}

\author{
ELIZABETH TURNER
}

\begin{abstract}
The band Herbs has recently been formally recognized in Aotearoa New Zealand for its cultural expression and influence, and for the musicians' political stance in an important period of activism. The band's highly original and influential first EP, What's Be Happen? (1981), is a musical fusion of roots reggae and Pacific sounds. It was the country's first Pacific reggae album and is regarded as a defining moment in the history of New Zealand popular music. This article examines "One Brotherhood," one of the most overtly political songs from that album, in relation to its political and social context. Written by band member Phil Toms, the song makes a powerful political statement by connecting protest against a national rugby tour of New Zealand by a racially selected team from Apartheid South Africa with struggles for the return of Māori land. I draw on Mikhail Bakhtin's theory of dialogism and his conceptualization of utterances as ethical acts in the analysis of this popular song and the ways in which subordinate voices are represented in its creative construction of protest and resistance to injustice and social oppression.
\end{abstract}

\section{Introduction}

When Nelson Mandela visited Aotearoa New Zealand ${ }^{1}$ in 1995, eighteen months after his swearing in as President of South Africa, he expressed his gratitude to the local anti-apartheid movement, its leaders and supporters. He thanked them for braving police batons in demonstrating against a 1981 tour of New Zealand by the racially selected South African rugby team (the Springboks), and for protesting against South Africa's "legalised and cruel system of racial domination." In recognition of its significance as part of the sound track of that struggle, New Zealand band Herbs' song "One Brotherhood" from their album What's Be Happen? ${ }^{4}$ was sung at a reception held for President Mandela in Auckland. What's Be Happen?, the first of the band's total of eight albums and New Zealand's first reggae album, is a musical fusion of reggae and Pacific sounds by a multi-ethnic group of musicians of Samoan, Samoan-Cook Island, Tongan, Māori, and Pākehā (European) heritage that produces a "distinctive Polynesian feel" ${ }^{5}$ and is seen as a

I would like to acknowledge Auckland University of Technology, New Zealand, for its support, including the granting of an Academic Staff Doctoral Study Award in 2013 to assist the completion of my doctoral thesis. I would also like to thank Associate Professor Sharon Harvey and Dr. Peter Hoar for their commitment and support; Herbs' songwriters Phil Toms and Toni Fonoti for their contribution to the study; and the reviewers for Music and Politics for their valuable comments and suggestions.

${ }^{1}$ The term Aotearoa New Zealand merges a Māori name for the country with the European name and is being increasingly adopted by writers and organisations in recognition of the bicultural foundations of the nation.

${ }^{2}$ Nelson Mandela as cited in Michael Daly and Katie Kenny, "Nelson Mandela's New Zealand Legacy," Stuff, December 6, 2013, http://www.stuff.co.nz/world/africa/9485493/Nelson-Mandelas-New-Zealand-legacy.

${ }^{3}$ Phil Toms, “One Brotherhood,” on Herbs, What's Be Happen?, Warrior Records, 1981, vinyl record.

${ }^{4}$ Herbs, What's Be Happen?, Warrior Records, 1981, vinyl record.

${ }^{5}$ John Dix, Stranded in Paradise: New Zealand Rock and Roll-1955 to the Modern Era (Wellington: Penguin, 2005$), 260$. 
musical watershed in the history of New Zealand popular music. ${ }^{6}$ Thirty-one years after the release of that EP, on September 13, 2012, Herbs were honored for their "enormous contribution to the cultural fabric of life" when they were inducted into the New Zealand Music Hall of Fame in Auckland's Town Hall. ${ }^{7}$ The band was recognized particularly for the fact that the six songs on What's Be Happen? commented on important social issues and were courageously political at a time when New Zealand had no history of political bands. Herbs' songs constituted a new voice for an audience that was becoming increasingly politically aware. ${ }^{8}$

The decade before the release of the album in 1981 is described as a significant period in New Zealand's modern history; ${ }^{9}$ a time of struggles over human rights, ethical values, and over the kind of society people wanted New Zealand to be. ${ }^{10}$ These are regarded as having shaped opinion and the sense of identity of many New Zealanders, ${ }^{11}$ and they led to significant and progressive changes in law.

In addition to demonstrations against the racism of South African apartheid and racially selected international rugby teams, there were protests over Māori land losses that had taken place as part of the process of colonization and its consequences in New Zealand. ${ }^{12}$ There were campaigns to end nuclear testing in the Pacific and to prevent degradation of the environment, as well as protests against racist treatment of so-called "over-stayers" from the Pacific Islands and of urban Māori and Pacific Island people. The 1970s also saw the rise of the feminist movement in Aotearoa New Zealand and elsewhere, campaigns against the sexual stereotyping and objectification of women, and significant protest movements in favor of homosexual law reform, abortion law reform and women's liberation. ${ }^{13}$ As I have argued elsewhere, ${ }^{14}$ Herbs' album forms a highly significant popular cultural nexus at the interface between music and politics in New Zealand in the early 1980s that connected, marked, and spoke to some of these issues. Herbs' music was popular with audiences in the early 1980s. It was central to the activism of Māori communities and those who organized and supported campaigns for change; it was a valued musical accompaniment to activist movements at that time that also helped to shape and to give voice to the oppressive experiences of peoples from the Pacific islands; it voiced and continues to voice the politics of these communities in a highly distinctive way.

The important and ongoing influence of What's Be Happen? on New Zealand music makers and in politically shaping and defining New Zealand music in the years since it was released was recognized in April 2015 when Herbs musicians, Warrior Records founder Hugh Lynn, and label and artist manager Will 'Ilolahia were awarded the Independent Music New Zealand (IMNZ) Classic Record award for the album. In the same year the impact and cultural standing of Herb's music was recognized when the band was awarded the Lifetime Achievement Award at the Pacific Music Awards in Auckland for What's Be

${ }^{6}$ Graham Reid, "Herbs, New Zealand’s Politicised Reggae Revolution: Hard Tings an’ Times," Elsewhere, September 2, 2012, http://www.elsewhere.co.nz/absoluteelsewhere/2753/herbs-new-zealands-politicised-reggae-revolution-hard-tings-an-times/.

${ }^{7}$ Australasian Performing Right Association Australasian Mechanical Copyright Owners Society (APRAAMCOS), "Herbs," APRA AMCOS New Zealand, 2012, http://www.apraamcos.co.nz/awards/awards/silver-scroll-awards/new-zealand-musichall-of-fame/herbs/.

${ }^{8}$ See Don McGlashan as quoted in "Herbs," APRA AMCOS New Zealand, 2012.

${ }^{9}$ See James Belich, Paradise Reforged (Auckland: Penguin, 2001).

${ }^{10}$ Historian Jock Phillips cited in Anthony Hubbard, "For a Good Cause," Sunday Star Times, August 29, 2010, C4.

${ }^{11}$ See Belich, Paradise Reforged, and Fohn Minto, "Protest and Dissent Were Everywhere," in Glory Days: From Gumboots to Platforms, ed. Ian Chapman (Auckland: HarperCollins, 2009).

${ }^{12}$ Joe Williams, "The Future of Maori Resource Management," in Beyond the RMA: An In-Depth Exploration of the Resource Management Act 1991. Conference Proceedings (Auckland: Environmental Defence Society, 2007).

${ }^{13}$ See Marilyn Waring, "A Feminist Perspective," in Glory Days: From Gumboots to Platforms, 155-158.

${ }^{14}$ See Elizabeth Turner, "What's Be Happen? A Dialogical Approach to the Analysis of Herbs' New Zealand Reggae Lyrics," Knowledge Cultures 3, no. 4 (2015): 91-115. 
Happen? and their second album Light of the Pacific. ${ }^{15}$ I argue here that What's Be Happen?, and "One Brotherhood" in particular, were important at the time and continue to be significant today for demonstrating the ways in which the appropriated and localized genre of Jamaican roots reggae can be inflected by Pacific musical traditions and mobilized as a Pacific "message music". Furthermore, in voicing protest and resistance to injustice and social oppression, Herbs' creative musical construction of salient social commentary speaks with political courage of important local concerns and critical struggles.

Four of the six songs on the album were written by Herbs' founding musician, songwriter and New-Zealand born Samoan Toni Fonoti, and address issues of day-to-day experience and identity ${ }^{16}$ related to Pacific Islands and Māori people in New Zealand. The title track "What's Be Happen?" questions the cultural dislocation, hardship and loss experienced by Pacific Islands people who, since the end of the Second World War, had moved to New Zealand to establish a better future for themselves and for their families. "Whistling in the Dark" recounts everyday experiences of racist treatment in encounters with the police in the 1970s and early 1980s. "Dragons and Demons" draws on biblical language, intertextual references to the Bible, and Rastafari spirituality to construct an implicit challenge to the influential authority of churches and their ministers in Pacific Island communities. The final song on the album, "Reggae's Doing Fine", is a tribute to Bob Marley, whose music and lyrics have had a great impact on Māori and Pacific Island audiences, ${ }^{17}$ and who died in May 1981 shortly before the album was released.

Side One of the album begins with one of the two most overtly political songs, "Azania (Soon Come)". The song protests against apartheid in South Africa on the eve of the notorious South African rugby football tour of New Zealand in 1981, and it was written for the band by law student Ross France. "One Brotherhood" is the equally political initial track on Side Two of the album and was written by Herbs' bass player Phil Toms, who is of Pākehā (European) descent. Toms' lyrics connect demonstrations against the South African rugby tour with protests against the historic and ongoing loss of Māori ancestral lands at Ōrākei in Auckland and Raglan in the North Island of New Zealand (see Figure 1). I focus here on the second of these two songs in a dialogic analysis of the meaning produced by relationships between the "combination of words and music"18 in "One Brotherhood" and the historical and political context at

\footnotetext{
${ }^{15}$ Herbs, Light of the Pacific, Warrior Records, 1983, vinyl record.

${ }^{16}$ The concept of identity employed here takes account of the influences of globalization (which include global flows of popular music) and acknowledges that identity development takes place in a context of intermixing cultures, cultural influences and histories (see Sunil Bhatia and Anjali Ram, "Rethinking 'Acculturation' in Relation to Diasporic Cultures and Postcolonial Identities," Human Development 44, no. 1-18 [2001], and Edward W. Said, Culture and Imperialism [London: Vintage, 1994].), as well as multiple, frequently contested cultural practices (Sunil Bhatia, "Rethinking Culture and Identity in Psychology: Towards a Transnational Cultural Psychology," Fournal of Theoretical and Philosophical Psychology 27-28, no. 21 [2007]: 301-21.). Multiple and commonly hyphenated identities (such as New Zealand-Chinese) are seen as historical, dialogical, and multi-voiced (see Hubert J.M. Hermans, "Mixing and Moving Cultures Require a Dialogical Self." Human Development 44 [2001]: 24-8), and are the consequence of constant negotiation between multiple dialogic voices, discourses, and histories (George Lipsitz, Dangerous Crossroads: Popular Music, Postmodernism, and the Poetics of Place [London and New York: Verso, 1994]; Mark B. Tappan, "Domination, Subordination and the Dialogical Self: Identity Development and the Politics of 'Ideological Becoming," Culture and Psychology 11, no. 1 [2005]: 47-75). Identity is viewed also as a positioning (Stuart Hall, "Cultural Identity and Diaspora," in Identity: Community, Culture, Difference, ed. Jonathan Rutherford [London: Lawrence and Wishart, 1990], 222-37), a dialogic and multiple positioning, and as a tool by which people identify who they are, and in doing so identify with or differentiate themselves from others (see Timothy J. Owens, "Self and Identity," in Handbook of Social Psychology, ed. John DeLamater [New York: Kluwer Academic/ Plenum Publishers, 2003] 205-32.). The performance and enacting of the process of identity formation in turn involves appropriations from popular culture and mass media (see Theodore Gracyk, I Wanna Be Me: Rock Music and the Politics of Identity [Philadelphia: Temple University Press, 2001]), in other words, the use of particular cultural tools and resources such as popular music.

${ }^{17}$ See Tony Fala, “A Riddim Resisting Against the System: Bob Marley in Aotearoa," (PhD thesis, University of Auckland, 2008).

${ }^{18}$ David Brackett, Interpreting Popular Music (Cambridge: Cambridge University Press, 1995), 29.
} 
that time. ${ }^{19}$ I begin with an examination of the song's political and social context. This is followed by a consideration of the meanings engendered by Herbs' appropriation of reggae. I then draw on Bakhtin's concepts and tools of analysis to examine "One Brotherhood." In extending Bakhtin's concepts and analytical tools to popular music the article makes a contribution to the field of Bakhtinian studies and popular cultural studies. It will be of interest to readers who are interested in reggae and in protest music, in the literary analysis of music and lyrics, as well as those with an interest in the cultural politics of New Zealand and the Pacific region. The analysis reveals that the song title, the reggae form in terms of tempo and tone, harmonized vocal performance as well as themes of apparent harmony in the lyrics of the chorus are juxtaposed with allusions to shouting, fighting, "wrecking the joint", and being knocked down by police batons. The song makes a powerful and creative political statement by connecting the struggles against colonial apartheid in South Africa with those in New Zealand against the effects of settler colonialism and land loss.

\section{Key Issues, Events, and Influences in Aotearoa New Zealand in the 1970s and 1980s}

In considering "One Brotherhood" as a social and political act that is inseparable from broader social relations, it is necessary to understand its context and the social circumstances in which it is rooted. Issues that led to widespread protest in New Zealand, such as indigenous rights, civil rights, and racism, were not in essence different from those that were being contested elsewhere, and they were influenced by political and economic struggles in other parts of the world. The American civil rights and anti-war movements, which in turn influenced the development of the so-called counter-culture and women's movements, had an impact on protest and activist movements in New Zealand. ${ }^{20}$

The Polynesian Panther Party, for example, founded in Auckland in 1971 by New Zealand-born Polynesians, was modelled on the American Black Panther Party and influenced by Huey Newton's concept of black unity. It sought to protect and advance the interests of Pacific Islands people including Samoans, Tongans, Niueans, and Māori in New Zealand, the largest island country in the Pacific, through political activism. The movement challenged and lobbied against practices and policies that discriminated against and divided these groups, including the "dawn raids" on Pacific Islanders' homes in the 1970s (see below). It advised people of their rights; operated food co-operatives and centers where students could do their homework in a quiet space; advised tenants of their rights and advocated for them; supported Pacific languages and promoted unity and pride in the cultural heritage shared by Pacific Island peoples. ${ }^{21}$ It also supported campaigns for the return of Māori land and the campaign to stop the South African Springbok rugby tour in 1981.

Other influences included wider access to television coverage of protests overseas after 1961 when television became more generally accessible, and easier and faster jet travel beginning in 1963. These allowed people in and from New Zealand to view and experience the realities of international events and movements such as anti-Vietnam War protests, the new counter-culture in the United States and protests

\footnotetext{
${ }^{19}$ The concept of dialogism and dialogic relationships was first developed by Bakhtin; Mikhail Bakhtin, "Discourse in the Novel," in The Dialogic Imagination: Four Essays by M.M. Bakhtin, ed. Michael Holquist (Austin: University of Texas Press, 1981).

${ }^{20}$ Michael King, The Penguin History of New Zealand (Auckland: Penguin, 2003).

${ }^{21}$ See Zoe Reid, "How the Polynesian Panthers Changed Our World," Salient, May 31, 2010.
} 
organized by the anti-apartheid movement. Conservative commentator William Buckley in the United States described the result of television coverage of protest demonstrations as the development of a new "contagion of protest". 22 In New Zealand that "contagion" spread to include protest against the country's involvement in the Vietnam War, described as the most significant and widespread public protest against government foreign policy in the country's history. ${ }^{23}$ It focused on the decision in 1965 of Prime Minister Keith Holyoake's National Party government to send NZ combat troops to assist the non-Communist government of South Vietnam. This provoked widespread demonstrations and protests involving people who opposed New Zealand's engagement in a war that was considered unjust and unjustified by a broad spectrum of opinion.

There were also anti-nuclear protests in opposition to French atomic bomb-tests in the Pacific region and their impacts on the peoples and the environment of the Pacific Islands and New Zealand. Herbs' song "French Letter" ${ }^{24}$ released as a single in 1982 and written by Toni Fonoti, voiced the anger of the great majority of New Zealanders who were strongly opposed to nuclear testing on ecological and moral grounds. The first of the French government's atmospheric nuclear tests in the South Pacific took place on Moruroa Atoll in French Polynesia in July 1966, and these above-ground tests did not end until September 15, 1974. The New Zealand government, led by Labour Prime Minister Norman Kirk, sent two frigates and a Cabinet Minister to join a flotilla of yachts in 1973 that sailed to the test area in protest. There were boycotts of French products, and in May 1973 New Zealand took a lawsuit against France to the International Court of Justice at The Hague to challenge the legality of the atmospheric tests. Although France undertook to end atmospheric testing in 1974, it subsequently began underground testing in 1975 at Moruroa and the nearby Fangataufa Atoll. With the exception of a suspension of testing after April 1992 until September 1995, French underground tests continued until February 1996. In New Zealand a campaign began in 1978 to declare people's cars, their houses, boroughs, and city council areas nuclearfree zones; in 1987 Labour government legislation declared the whole of New Zealand a nuclear-free zone.

A further important element of the social, political, and economic context for Herbs' album was the increase in unemployment in New Zealand in the 1970s and a subsequent increase in racist attitudes towards immigrants from the Pacific islands. In the 1960s declining opportunities for employment in the Islands combined with industrial development and full employment in New Zealand led increasing numbers of migrants, with encouragement from government and businesses, to seek work, higher incomes, better living standards and educational opportunities in New Zealand, ${ }^{25}$ which had at that time one of the highest average standards of living in the world. However, as a result of the six-month embargo on oil sales imposed in October 1973 by the Organization of Arab Petroleum Exporting Countries, world oil prices quadrupled. New Zealand was not immune to the impacts of the oil crisis and faced its greatest economic difficulties since the 1930s. Inflation averaged $10 \%$ and reached $18 \%$ in 1976; there was a large domestic budget deficit and several devaluations of the New Zealand dollar. ${ }^{26}$ For migrants from the Pacific Islands the reality of overcrowding and inadequate housing, economic hardship and marginalization was exacerbated by government policies with clear racist overtones that targeted Pacific

\footnotetext{
${ }^{22}$ Cited in King, Penguin History of New Zealand, 452.

${ }^{23}$ Keith Sinclair, A History of New Zealand (Auckland: Penguin, 1988).

${ }^{24}$ Toni Fonoti, "French Letter," on Herbs, French Letter, Warrior Records, 1982, vinyl record.

${ }^{25}$ Margaret Boyd, "New Zealand and the Other Pacific Islands," in The Oxford Illustrated History of New Zealand, ed. Keith Sinclair (Oxford: Oxford University Press, 1993).

${ }^{26}$ Sinclair, History of New Zealand.
} 
Islands people. These included dawn raids in 1974 and 1976 on the houses of Pacific Islands people who were suspected of staying beyond the terms of their entry permits (so-called over-stayers) ${ }^{27}$ and arrests and random police checks on Polynesian-looking people on the streets of Auckland. For many New Zealanders this treatment of people from the Pacific Islands by Prime Minister Muldoon's National government mirrored the treatment of the black population in apartheid South Africa.

The economic downturn caused by the oil crisis and increasing unemployment in the 1970s also affected Māori people who in the period since the Second World War had migrated from rural areas of New Zealand to urban centers, and with government encouragement had taken up industrial employment in large numbers. By 1981, the overall unemployment rate for Māori was 14.1 percent, compared to 3.7 percent for New Zealanders of European descent. ${ }^{28}$ At the same time, there was a significant increase in Māori self-assertion and radicalism, and a new Māori activist movement emerged at the end of the 1970s with a political ethos based on the struggle for liberation from racism and from cultural and economic oppression. $^{29}$

Like the other tracks on Herbs' album What's Be Happen?, "One Brotherhood" was recorded just before the beginning of the controversial South African rugby tour of New Zealand in 1981. In the southern hemisphere winter of that year, Nelson Mandela was imprisoned on Robben Island, and the South African national rugby team, the Springboks, was about to begin a tour of New Zealand. The South African team, with one "token black player" would be touring a country divided by conflict between those who opposed and those who supported the tour. ${ }^{30}$ The tour was to take place with government approval in spite of widespread opposition to the "moral genocide"31 of apartheid and in defiance of local advice; the United Nations' call to end sporting exchanges with the apartheid regime; and the Gleneagles Agreement in which every Commonwealth government had agreed to discourage contact with South African sporting organizations. ${ }^{32}$ Furthermore, it was to take place in a country where many Pacific Islands people in Auckland had had their homes raided and had been subjected to random police checks on the racist suspicion they might be over-stayers, and where a cultural resurgence among Māori-and increasing political consciousness on the part of urban Māori in particular-saw renewed attempts to reclaim the lands they had lost under British colonial rule.

Māori land gained ground as a major issue in the mid-to-late 1970s in protests against land confiscation and land losses over many years. The consequences of colonization and of the subsequent neglect of Māori interests by governments in the period of post-colonization had led to a significant loss of culture, language, and land. ${ }^{33}$ Limited changes that recognized Māori interests had been introduced by the Labour Government of 1972 to 1975. These included the introduction in 1975 of the Waitangi Tribunal. Named after the Treaty of Waitangi that was signed by Māori iwi (tribes) and the British Crown in 1840, the tribunal was set up to hear Māori land grievances, investigate claims submitted as breaches of the Treaty, and make recommendations to Parliament on their resolution. However, the tribunal was severely limited in that it had restricted retrospective powers, and changes did not adequately address Māori grievances over land rights, nor the unrelenting erosion of Māori rights to the remaining 1.2 million

\footnotetext{
${ }^{27}$ As explained, for example by Boyd, "New Zealand."

${ }^{28}$ Belich, Paradise Reforged.

${ }^{29}$ Ranginui Walker, Ke Whawhai Tonu Matou: Struggle without End, 2nd ed. (Auckland: Penguin, 2004).

${ }^{30}$ Kathryn Ryan, "Feature Guest- Dilworth Karaka," Nine to Noon, Radio New Zealand, December 24, 2012.

${ }^{31}$ John Carlin, Playing the Enemy: Nelson Mandela and the Game That Made a Nation (London: Atlantic Books, 2008$), 2$.

32 Sinclair, History of New Zealand.

${ }^{33}$ Williams, "The Future of Maori Resource Management."
} 
hectares of their land as a result of European New Zealanders' laws. ${ }^{34}$ These included the more recent Rating Act 1967, which allowed local authorities to lease or sell rural Māori land that was unoccupied as a result of Māori migration to urban areas, and the Māori Affairs Amendment Act 1967—the "last land grab" by Pākehā (Europeans). ${ }^{35}$ The latter enabled the compulsory purchase and sale of Māori land by the Crown, and allowed for the re-designation of Māori land owned by fewer than four people as European land. Dissatisfaction and frustration over the treatment of Māori land rights led to the formation of an influential Māori land rights movement, and in 1975 there was a march from the far north of New Zealand to Parliament in Wellington. The Māori Land March or hikoi, with the slogan "Not one more acre of Māori land," was on the road for a month and half and stopped en route at twenty-five marae (Māori sacred meeting areas, usually located in front of a communal meeting house). The hikoi politicized Māori people, particularly in terms of historic land losses in the struggle against colonization and claims for the return of lost lands, and drew the attention of Pākehā New Zealanders and the New Zealand government to the issue. ${ }^{36}$

The Land March was followed by protests in 1978 about the use of Māori land at Raglan (Whāingaroa in the North Island) for a golf course, and a campaign for the return of that land, which had great traditional significance for local Māori, to Māori ownership. ${ }^{37}$ Originally requisitioned during the Second World War as a military airfield but eventually not needed for that, part of the land was used in 1969 for a golf course. As a result of protests the land at Raglan was eventually returned to the Tainui Awhiro people. These activities, along with the seventeen-month protest occupation for the return of Ngāti Whātua land at Bastion Point in Ōrākei, Auckland, and the use of force to end it, played an important part in highlighting and focusing national attention on long-standing injustices against Māori people, and eventually in improving conditions for Māori and modifying Māori-Pākehā understandings. ${ }^{38}$

The contextual and political importance of the protest at Bastion Point for Herbs' album is articulated unambiguously by the incorporation of a black and white aerial photograph of the final day of the occupation, which dominates the front of the album cover. The image shows the highly contentious eviction of Māori land rights protesters by police, with the assistance of the army, on the final day of the Bastion Point occupation on May 25, 1978. The events at Bastion Point are seen as a culmination of the "sordid tale of colonial oppression of the once proud owners of Tāmaki Makaura [Auckland]". ${ }^{39}$ In 1854, seven acres of a beautiful part of the city of Auckland on the east coast overlooking the Hauraki Gulf at Bastion Point had been gifted to the Crown by the Ngāti Whātua iwi on condition that these should be returned if not used for defense. This land had not been returned, and in 1885 a further thirteen acres had been taken under the Public Works Act for a battery reserve in defense against a possible Russian attack. ${ }^{40}$ In 1976, in a move that triggered the occupation protest, New Zealand's National Government announced a Crown decision to subdivide and sell the twenty-four hectares ${ }^{41}$ of Māori land at Bastion Point to the highest corporate bidder for high-income housing development. Prime Minister Robert Muldoon, in an

\footnotetext{
${ }^{34}$ Walker, Ke Whawhai Tonu Matou: Struggle without End.

${ }^{35}$ Ibid., 207.

${ }^{36}$ Ibid.

${ }^{37}$ See King, Penguin History of New Zealand.

${ }^{38}$ King, Penguin History of New Zealand; Renee Hawke cited in Bastion Point: The Untold Story, directed by Bruce Morrison, originally broadcast as an episode of the TV3 documentary series Inside New Zealand (1999; Auckland: Morrison Grieve and Moko Productions).

${ }^{39}$ Walker, Ke Whawhai Tonu Matou, 215.

${ }^{40}$ See Land of a Thousand Lovers, directed by Wayne Tourell, 1977; originally broadcast as part of the Perspective series.

${ }^{41} 24$ hectares is approximately 60 acres.
} 
offensive and racist comment targeted at Māori who lived on this land, considered that the development would "clean up the area nicely." 42

In response to the government's announcement, the Orakei Māori Action Committee was formed to prevent the subdivision by organizing direct action and occupation of the ancestral iwi lands in January 1977. ${ }^{43}$ Support from a range of organizations strengthened the occupiers' position and the government was asked to return a total of seventy-two acres of land to Māori. ${ }^{44}$ The Crown's response was to file for an injunction from the Supreme Court for the occupiers to vacate the land. On May 25, 1978, after an occupation of seventeen months, the government employed the police and the army to eject the occupiers by force in the largest ever police operation in Aotearoa New Zealand. All traces of the occupation were destroyed and more than two hundred protesters were arrested.

The local and international issues and struggles outlined here formed the social, political, and economic context for activist politics in Aotearoa in the 1970s and 1980s. They created the conditions for Herbs to emerge as "a multicultural, sociopolitical powerhouse" 45 that forged connections between Pacific reggae, the world-wide anti-apartheid movement, protests against the injustice of historical Māori land losses and the exploitation of former Māori lands, and movements that challenged the racist legacy of colonialism.

When Herbs were formed from an earlier Auckland band, "Backyard" in the late 1970s, songwriter, musician and founding member of the band Toni Fonoti had read the work of Huey Newton and had met and talked at length to Bob Marley after his concert in Auckland in 1979 as part of Marley and the Wailers' Babylon by Bus tour. Marley's music, which spoke of rights, justice, resistance, and liberation, had particular meaning for Māori and Pasifika audiences. And at a time of gang tensions between the youth of Pacific Islands communities in New Zealand and when most Pacific Islands musicians were covering other people's music rather than writing their own, Fonoti saw reggae as a vehicle that expressed people's concerns, and raised consciousness of "who we are as a people and our rights as a people." ${ }^{\text {" In forming }}$ Herbs Fonoti had the ambition to bring the different ethnic groups together under the umbrella of a music that could connect them. By the end of 1980, along with their new bass player Phil Toms, who wrote "One Brotherhood," and Māori guitarist Dilworth Karaka, Herbs also had a manager, Will 'Ilolahia, one of the six founding members of the Polynesian Panthers.

\section{A Bakhtinian Framework for Analysis}

It is particularly fitting to frame "One Brotherhood," a song that speaks of such political struggles over human rights, in an approach that draws from the philosophy and theories of Russian philosopher and literary critic Mikhail Mikhailovich Bakhtin (1895-1975). Bakhtin is among the twentieth century's most significant literary theorists; his multi-faceted theory of dialogism which conceives meaning as a relational phenomenon contingent on social and cultural context, and his approach to literary analysis and dialogic intersubjectivity continue to be productive across the contemporary humanities. His theories and

\footnotetext{
42 Tourell, "Land of a Thousand Lovers."

${ }^{43}$ See Orakei Maori Committee Action Group, Takaparawha Bastion Point : 506 Days on Ancestral Maori Land : Bastion Point

Defenders Reply to Government and Fustice Speight (Auckland: Orakei Maori Committee Action Group, 1978).

${ }^{44}$ Walker, Ke Whawhai Tonu Matou.

${ }^{45}$ Glen Moffatt, "Herbs History," Herbs, 2013, http://www.glenmoffatt.com/herbs history.htm.

${ }^{46}$ Toni Fonoti, interview by Fraser Goodman, "Poly Cafe: My Dream “The Creation of the Herbs Band-What's Be

Happen!” Poly Cafe (audio blog), 2010.
} 
analyses valorize the products of popular culture, which he views in Ken Hirschkop's words as "the privileged bearer of democratic and progressive values, ${ }^{47}$ and politicize language and discourse. ${ }^{48}$ In Bakhtin's focus on the dialogic construction of meaning and understanding he conceptualizes utterances as responsible moral deeds, ${ }^{49}$ as acts of ethical position taking ${ }^{50}$ in which choices of language are ethical choices. ${ }^{51}$ Equally importantly, while some theorists argue that the study of discourse "can involve matters like context and background information," "52 Bakhtin repeatedly emphasizes the effect on discourse of the specific social environment at a particular "historical moment." 53 The shaping environment involves not only the discursive context of other utterances, against which meaning is understood, as Bakhtin argues, but, as Craig Brandist points out, by extension of Bakhtin's ideas it includes historical political and economic events and influences. ${ }^{54}$

\section{Herbs' Pacific Reggae}

Before moving on to focus on Herbs' song "One Brotherhood" I draw on Bakhtin's theorization of verbal genres and appropriation of language to consider the band's appropriation of Jamaican roots reggae. ${ }^{55}$ Bakhtin argues that the intentions of language users are expressed primarily in their choice of a particular verbal genre. ${ }^{56}$ As has been argued elsewhere, ${ }^{57}$ in addition to being an aesthetic choice, Herbs' appropriation of reggae as a musical genre can by extension of Bakhtin's ideas be seen as an orientation that carries complex overtones of meaning and, in Stuart Hall's terms, is a positioning. ${ }^{58}$ It is a positioning that relates to understandings of reggae as message music and a weapon against oppression and injustice; ${ }^{59}$ to the cultural domain of the African diaspora as a source of oppositional practice and alternative values; to reggae's roots among the oppressed sufferahs of Jamaica as well as to what George Lipsitz describes as the "sedimented currents of opposition" in reggae's past; ${ }^{60}$ and to global cultural connections created by reggae as a practice of resistance. ${ }^{61}$ By extending Bakhtin's notion of appropriated language ${ }^{62}$ to music, "One Brotherhood," along with Herbs' other Pacific reggae songs on the album, can be understood to illustrate the way in which language becomes someone's own when it is appropriated and populated with the

\footnotetext{
${ }^{47}$ Ken Hirschkop, "Bakhtin, Discourse and Democracy," New Left Review 1, no. 160 (1986).

${ }^{48}$ Hirschkop, "Bakhtin, Discourse and Democracy."

${ }^{49}$ Mikhail Bakhtin, "The Bildungsroman and Its Significance in the History of Realism (toward a Historical Typology of the Novel)," in Speech Genres and Other Late Essays, ed. Caryl Emerson and Michael Holquist (Austin, TX: University of Texas Press, 1986).

${ }^{50}$ Ken Hirschkop, Mikhail Bakhtin: An Aesthetic for Democracy (Oxford: Oxford University Press, 1999), https://doi.org/10.1093/acprof:oso/9780198159612.001.0001.

${ }^{51}$ See Greg Nielsen, "Bakhtin and Habermas: Toward a Transcultural Ethics “ Theory and Society 24, no. 6 (1995), https://doi.org/10.1007/BF00994066.

${ }^{52}$ Meriel Bloor and Thomas Bloor, The Practice of Critical Discourse Analysis: An Introduction (London: Hodder Arnold, 2007), 7. (emphasis added)

${ }^{53}$ Bakhtin, The Dialogic Imagination: Four Essays by M.M. Bakhtin, 276.

${ }^{54}$ Brandist, The Bakhtin Circle: Philosophy, Culture and Politics (London: Pluto Press, 2002). See also Turner, "What's Be Happen?"

${ }^{55}$ Roots reggae as defined by Thomas Weber is the form popularized internationally by Bob Marley and others, featuring full instrumentation and harmonized vocals. See Thomas J. Weber, "Likkle but Talawah (Small but Mighty): Reggae Music, Globalization, and the Birth of a Social Movement" (PhD diss., Bowling Green State University, 2000).

${ }^{56}$ Bakhtin, "The Problem of Speech Genres," in Speech Genres and Other Late Essays.

${ }^{57}$ See Turner, "What's Be Happen?"

${ }^{58}$ Stuart Hall, "Cultural Identity and Diaspora."

${ }^{59}$ See Weber, "Likkle but Talawah."

${ }^{60}$ Lipsitz, Dangerous Crossroads, 103.

${ }^{61}$ Alvarez, "Reggae Rhythms in Dignity's Diaspora," 54, https://doi.org/10.1080/03007760802188272.

${ }^{62}$ Bakhtin, The Dialogic Imagination.
} 
individual's accent and intentions. In a hybrid form that adapts Jamaican reggae and its Rastafari influences to their semantic and expressive intentions, the musicians draw on Pacific musical traditions such as Pacific Island drumming, Polynesian guitar strumming style and Pacific-style harmonization to produce the distinctive sound of Herbs' music. It is a Pacific style of reggae that is less rhythmically complex, ${ }^{63}$ less snappy, less staccato, and has more of a "rolling" style than Jamaican roots reggae. ${ }^{64}$ As Jennifer Cattermole has pointed out, the incorporation of elements of Pacific musical traditions such as these can be seen as a means for musicians in Aotearoa New Zealand to assert their connections to their ancestral island homelands and to construct and sustain their Pacific cultural identities. ${ }^{65}$

Viewed through the lens of Bakhtin's theory of dialogism, meanings emerge from and between reggae's roots, associations, and rhetorical overtones and from their dialogic relationship to Pacific musical traditions, and the themes and referents of Herbs' songs. Meanings associated with colonization of Aotearoa New Zealand and the impacts of its aftermath on Māori and the Pacific Island population are inflected by their dialogic relationship with the struggles of the sufferahs of Jamaica and their African cultural traditions. Meanings can also be understood to be modulated by Rastafari's dedication to racial pride and self-esteem, ${ }^{66}$ by Rastafari spirituality, and by what Christine Chivallon describes as the emphasis of Rastafari on a freedom and democracy that is resistant to constraining and oppressive norms and centralization. ${ }^{67}$

\section{Form and Content in "One Brotherhood"}

While the title of "One Brotherhood" is suggestive of harmony, the relationships between lyrical content and form, and features of musical and performed form signify and construct conflict. ${ }^{68}$ Consideration of these relationships is underpinned by Bakhtin's emphasis on the constituent relationship between form and content in relation to meaning. For Bakhtin (in his focus on the modern novel) "form and content in discourse are one." ${ }^{99}$ That is, Bakhtin recognizes the duality of every artistic sign, in which "all content is formal and every form exists because of its content", and in which form is active as a particular aspect of a "message." 70 The contemporary literary and cultural theorist Terry Eagleton similarly stresses the inseparable relationship in poetry between meaning and verbal form, which are so intimately interwoven that form becomes "constitutive of content." structures of language," 72 the same can be said of the lyrics of certain types of popular song.

"One Brotherhood" begins in a way that is suggestive of harmony between humankind and nature, with the sound of waves gently breaking on a shingle beach, joined by the cries of seagulls. The rhythm of

\footnotetext{
${ }^{63}$ Phil Toms in personal communication, November 21, 2013.

${ }^{64}$ Musician Charlie Tumuhai quoted in Jennifer Cattermole, “'Oh, Reggae but Different!': the Localisation of Roots Reggae in Aotearoa," in Home, Land and Sea: Situating Music in Aotearoa Nerw Zealand, ed. Glenda Keam and Tony Mitchell

(Auckland: Pearson, 2011).

65 "The Routes of Roots Reggae in Aotearoa/New Zealand: The Musical Construction of Place and Identity" (master's thesis, University of Otago, New Zealand, 2004).

${ }^{66}$ See Lloyd Bradley, Bass Culture: When Reggae Was King (London: Penguin, 2000).

${ }^{67}$ Christine Chivallon, "Beyond Gilroy's Black Atlantic: The Experience of the African Diaspora," Diaspora 11, no. 3 (2002), https://doi.org/10.1353/dsp.2011.0055.

${ }^{68}$ Hear Herbs' "One Brotherhood" at https://www.youtube.com/watch?v=OVMRtK11Vaw.

${ }^{69}$ Bakhtin, "Discourse in the Novel," 259.

${ }^{70}$ Krystyna Pomorska in the Foreword to Mikhail Bakhtin, Rabelais and His World, trans. Helene Iswolsky (Bloomington: Indiana University Press, 1984), viii.

${ }^{71}$ Terry Eagleton, How to Read a Poem (Oxford: Blackwell, 2007), 67.

${ }^{72}$ Eagleton, How to Read a Poem, 52.
} 
these cries is taken up by the drummer in the four-bar instrumental introduction and, as Phil Toms has pointed out ${ }^{73}$ establish the tempo of the song's relaxed reggae beat. Harmonized voices in the chorus, which is literally and metaphorically polyphonic ${ }^{74}$ ("We're one brotherhood Aotearoa"), combined with the legato musical style, gentle instrumental bridges, and recorded sound effects, serve to evoke soothing sounds of the Pacific Ocean and a sense of the relaxed spirit invoked by beaches on "a paradise island" in Aotearoa.

There are, however, significant contrasts between musical and lyrical tone and referential content. The first line of the chorus, "We're one brotherhood, Aotearoa" (see Figure 1), continues the tone of harmony established in the instrumental introduction. The second line, "Fighting man against man in the eleventh hour", however, produces a discordant contrast with the force of the initial tone. This pattern is repeated when the third line, "Brother and sisterhood, yeah, Aotearoa," which parallels the first line thematically and revives the theme of harmony, is in turn juxtaposed with the contrasting final line of the chorus: "Together we'll stand together we have power." The lyrics thus produce what Eagleton refers to as a "baffling of expectations" 75 in the unexpected shift from the idea of one brotherhood and one sisterhood and connotations of idealized harmony between people and peoples, to the notions of fighting, of Aotearoa being on the brink of disaster ("in the eleventh hour"), and of an unexplained but urgent need to "stand together."

(Chorus)

We're one brotherhood, Aotearoa

Fighting man against man in the eleventh hour

Brother and sisterhood yeah, Aotearoa

Together we'll stand together we have power

(Verse one)

So you knock me down

With your modunok baton

'Cause I cause a big stir

about the bad things goin' on

'Cause it's a cover up

about the goal posts and the slaves

But you'd rather not know

'Cause time is dealing out your days

(Chorus)

We're one brotherhood...
(Verse two)

Well they're fighting for land in Raglan

And they're fighting for land in Orakei

And they're shouting in Parliament

People trying to get free

On a paradise island

Crazy people wanting more, more, more

And they're wrecking the joint

While they take from you and me

(Chorus, repeated)

We're one brotherhood...

We're one brotherhood...

We're one brotherhood...

We're one brotherhood...

Figure 1: Lyrics of "One Brotherhood" (Toms, 1981). Non-italic text signifies the lead vocalist, Phil Toms; italics signify multiple, harmonized voices.

For New Zealand audiences who had lived through events related to what was referred to as the "Haka Party Incident" in 1979, these juxtapositions may initially have appeared to be satirical. These events

\footnotetext{
${ }^{73}$ Personal communication, November 21, 2013.

${ }^{74}$ Bakhtin introduces the term polyphonic in his analysis of Dostoevsky's novels, which are characterised by an innovative type of metaphorically or multi-voiced artistic thinking that involves "a plurality of independent and unmerged voices and genuine consciousnesses, a genuine polyphony of fully valid voices." See Bakhtin, Problems of Dostoevsky's Poetics, trans. Caryl Emerson (Manchester: Manchester University Press, 1984), 6, https://doi.org/10.5749/i.ctt22727zl. (Bakhtin's emphasis).

${ }^{75}$ Eagleton, How to Read a Poem, 92.
} 
shocked Pākehā New Zealand by repudiating the myth that the country was a "multicultural utopia"76 and rupturing the dominant ideology that posited Māori and Pākehā as one harmonious people..$^{77}$

Students at the University of Auckland's School of Engineering had been parodying the culturally significant Māori haka (Māori ceremonial war dance) for many years, and Māori students had been trying to negotiate an end to this culturally offensive annual performance through formal channels for at least ten years. In 1979, a group of Māori activists confronted the engineering students while they were practicing for the planned performance at the end-of-year capping day celebrations, in order to end it. In the scuffle that developed, the students' grass skirts were forcibly removed and some suffered bruising and cuts.

According to Professor Ranginui Walker, the press "whipped up Pakeha hysteria into a general condemnation of violence"; the incident was perceived as a threat to the state's control and to "the structurally assigned place of Maori subjection to Pakeha." ${ }^{97}$ However, the notion that the only view of the incident was one of outraged Pākehā condemnation of the activists was challenged when it was learned that they had the support of prominent Māori leaders and the Auckland District Māori Council, whose chairman was arguing that the activists' physical violence was no worse than the cultural violence of the engineering students' haka. When it later became known that the students had used lipstick to paint their bodies with sexual caricatures as "tattoos", the New Zealand Māori Council and Māori Women's Welfare League also decided to support the activists. The presence of the presidents of all three organizations along with many other Māori supporters at the subsequent court hearing was seen not only as an expression of Māori solidarity, but also as providing a social context for the hearing in which the mana (prestige) of the judge was equaled by the mana of the Māori people and their significant organizations. In Professor Walker's view, the court was in effect transformed into a representation of the clash between Māori and Pākehā cultures. The judge's understanding that this was a political case involving conflict between the two cultures, along with the testimony of Māori elders, led to the activists being found guilty of assault but sentenced to periodic detention rather than imprisonment.

This incident is seen as having exposed "the raw nerve of racism in New Zealand society". ${ }^{79}$ It prompted an inquiry by the New Zealand Race Relations Conciliator and the Human Rights Commission whose first report Racial Harmony in New Zealand, ${ }^{80}$ widely quoted and debated in the press, ${ }^{81}$ categorized submissions into those that promoted the ideology of "one people", whom Professor Walker describes as evidencing "entrenched attitudes of racial, social and cultural superiority" ${ }^{\prime 2}$, and those that argued for recognition of New Zealand as a bi-cultural and increasingly multicultural society. A second, more extensive report with recommendations to the government and entitled Race Against Time expressed a sense of urgency:

We are at a turning point in regard to harmonious race relations. . the myth of New Zealand as a multicultural utopia is foundering on reality. Since Bastion Point, the Haka Party Incident and recent disturbances at Waitangi [the center of Treaty of Waitangi celebrations held on February 6 each year], there has been heightened awareness regarding racial conflict. ${ }^{83}$

\footnotetext{
${ }^{76}$ Human Rights Commission, "Race against Time," (Wellington: Race Relations Conciliator, 1982), 12.

${ }^{77}$ Walker, Ke Whawhai Tonu Matou.

${ }^{78}$ Ibid., 222.

${ }^{79}$ Ibid., 225.

${ }^{80}$ Human Rights Commission, "Racial Harmony in New Zealand: A Statement of Issues," (Wellington, 1979).

${ }^{81}$ See for example, "Search for harmony," New Zealand Herald, April 10, 1980.

${ }^{82}$ Walker, Ke Whawhai Tonu Matou, 225.

${ }^{83}$ Human Rights Commission, "Racial Harmony in New Zealand,” 12.
} 
Ranginui Walker argues that although these reports did not lead to any immediate changes, the cumulative impact of Māori activism led eventually to "profound social changes" in the 1980s, which moved New Zealand into the post-colonial era. ${ }^{84}$

Rather than the song being an exercise in irony, relationships embedded in the lyrics of "One Brotherhood" suggest a different complexity of meaning. In particular, the phonic association in the endrhyme "hour / power" creates a dialogic semantic relationship that suggests an urgent "eleventh-hour" need for the power produced by the solidarity and political unity of sisterhood and brotherhood. Toms' description of himself at the time the song was written supports this interpretation: "I was a political person at the time... I'd been going on Vietnam demonstrations since I was about 17 and anti-nuclear ships demonstrations... I was part of that left-wing movement." ${ }^{85}$ Toms can be understood to have appropriated and re-accented ${ }^{86}$ the terms "brotherhood" and "sisterhood". Appropriated from the context of a mythical racial harmony associated with European liberal ideology in New Zealand, in a different evaluative context, ${ }^{87}$ the terms are imbued with meanings related to solidarity in the face of oppression and inequality. The phrase "We're one brotherhood" can be understood therefore as a "rhetorical exhortation," ${ }^{88}$ an appeal for the solidarity necessary to resist oppression.

\section{Dialogic Relationships, Authorial Choices and the Chronotope in "One Brotherhood"}

Dialogic associations in the two verses elaborate indirectly on the nature of the oppression suggested in the discourse of the chorus. There is a shift in addressee from "Aotearoa" (in the chorus) to "you" and "your" in the first verse that appear to address the police in New Zealand. The force had been equipped with a new, much longer Monadnock baton, partly in preparation for protests against the scheduled Springbok tour. ${ }^{89}$ The Museum of New Zealand Te Papa's description of an exhibited baton frames the use of these in the context of "riot control". 90 The lyrics, in contrast, construct a different point of view, evoking images of noisy demonstrators against injustice being struck down by baton-wielding riot squads: "Cause I make a big stir / about the bad things goin' on". The lyrics in the second half of the verse suggest the righteous focus of some of the big noise protests. In the lines "Cause it's a cover up / about the goalposts and the slaves", the reference to goalposts evokes rugby football and the Springbok tour. At the same time, in the context of the idiom about shifting goalposts, the word relates to political motivations, to the political shifting of rules. Given the contemporaneous context, this notion of moving the goalposts is likely to refer among other possibilities to the inclusion of the single black player, Errol Tobias, in the Springbok team. Seen as a token of multi-racialism, Tobias' selection can be interpreted as an attempt to deflect protests that might disrupt the rugby matches, and as part of a strategy to frustrate the struggle for

\footnotetext{
${ }^{84}$ Walker, Ke Whawhai Tonu Matou, 225.

${ }^{85}$ Personal communication November, 21, 2013.

${ }^{86}$ Bakhtin, The Dialogic Imagination.

${ }^{87}$ See Valentin Nikolaevich Voloshinov, Marxism and the Philosophy of Language, trans. Ladislav Matejka and I.R. Titunik (Cambridge, MA: Harvard University Press, 1986 ).

${ }^{88}$ Terry Eagleton, The Event of Literature (New Haven and London: Yale University Press, 2012), 119.

${ }^{89}$ Phil Toms had heard the name as "modunok." He explains that the baton "was creating a bit of an outrage. . They got in these special container loads for the Springbok tour. Because they were going to have to hit a whole lot of people over the head." (personal communication, November 21, 2013).

${ }^{90}$ Te Papa has an exhibit of the 60-cm., US-made Monadnock PR 24 baton, "introduced. . . in the early 1980s for riot control." See http://collections.tepapa.govt.nz/objectdetails.aspx?oid=66823.
} 
majority rule in South Africa. As Bishop Desmond Tutu pointed out at the time, it simply made the chains of the slavery of apartheid less uncomfortable ${ }^{91}$ and did nothing to change the racist regime in South Africa.

The most obvious interpretation of the final lines of the first verse, "But you'd rather not know / Time is dealing out your days", is that these words are addressed to the apartheid regime. However, the lyrics create a dialogic relationship between the impending Springbok tour and conflicts over Māori land rights by the juxtaposition of content in the first verse with the references to struggles to regain land in the second verse ("They're fighting for land in Raglan. . . in Orakei"). This has the significant political effect of connecting the racism of apartheid South Africa to racist colonial policies of land seizure in New Zealand, and more recent policies of land acquisition and unjust government tenure of Māori land. By implication, the "you" in "you'd rather not know" addresses institutionalized racism and racists in New Zealand as well as the racist regime in South Africa.

This implication is reinforced by an examination of the relationships constructed in the first-person narrative of the song through the lens of Bakhtin's notion of the chronotope ${ }^{92}$ (the differing representation of time and space in literary texts). The chronotope provides a theoretical framework for consideration of meanings engendered by the relationship between generally held concepts of time at a given moment in a particular culture, the chronology of events in "real life", and the ways in which a sequence of events is "deformed" in a mediated narrative. ${ }^{93}$ With the exception of a reference to an unspecified "eleventh hour" in the chorus and a generalized reference to the passing of time in the last line of the first verse ("time is dealing out your days"), the use of the present tense is the only indicator to locate the narrative of "One Brotherhood" in time. Furthermore, while the space of "Aotearoa" is identified in the chorus, there is otherwise an absence of indicators in the first verse to locate the narrative in a particular space or place. The effect of authorial choices to omit such details along with the choice of tense suggest the use of the gnomic present tense to express a general and ongoing truth or reality. The "I" and "me" in the direct authorial narrative of the first verse can be understood to include the narrator, the New Zealander who plans to protest against the impending Springbok tour, ${ }^{94}$ the South African who resists apartheid, and those such as Bantu Steve Biko who have suffered, suffer, and will suffer violence fighting in support of this cause.

While the present tense is also used in the second verse, this verse includes the names of specific places in a series of parallel structures: "Well they're fighting for land in Raglan / And they're fighting for land in Orakei / And they're shouting in Parliament”. References to local place names are said to engender a distinct sense of place; ${ }^{95}$ through the framework of the chronotope, however, these names and their associations with significant struggles to regain lost Māori lands can also be seen as part of the construction and expression of a political position. Their inclusion serves rhetorical purposes by locating the narrative in specific places "charged with social and cultural meanings" in the spatial environment of Aotearoa New

\footnotetext{
${ }^{91}$ Bishop Desmond Tutu cited in Paddy Moore, "Address to Local [Christchurch] Hart Branch [Transcription]," University of Canterbury Springbok Tour Archive, no. 73 (June 1981): 292-97, http://digital-

library.canterbury.ac.nz/data/library3/archives/113561.pdf.

${ }^{92}$ Bakhtin, "Forms of Time and of the Chronotope in the Novel," in The Dialogical Imagination: Four Essays by M.M. Bakhtin, ed. Michael Holquist (Austin, TX: University of Texas Press, 1981).

${ }^{93}$ Michael Holquist, Dialogism: Bakhtin and His World (London: Routledge, 1990), 115, https://doi.org/10.4324/9780203330340.

${ }^{94}$ See Merata Mita, dir., Patu!, (New Zealand: Awatea Films, 1983).

95 Tony Mitchell, Popular Music and Local Identity: Rock, Pop and Rap in Europe and Oceania (London: Leicester University Press, 1996).
} 
Zealand. ${ }^{96}$ In locating the narrative in particular places with names that evoke significant past events in the 1970s and doing so in the present tense, what would generally be regarded as a sequence of events in recent past time (given that the song was written in 1981) is therefore creatively "deformed", condensed, and concentrated in present time. ${ }^{97}$ The effect is to suggest that these struggles are ongoing. By means of juxtaposition and tense use they are dialogically connected to the narrative of protest, goalposts, batons, and "slaves" in the first verse.

\section{Conclusion}

The enduring political significance of the events and issues referenced in "One Brotherhood" is evidenced in the continuing circulation of related discourses. There are ongoing references, for example, to the polarizing effect of the 1981 South African rugby tour of New Zealand at the time ${ }^{98}$ and to the contribution that New Zealanders' protests against the tour made to the struggle to overthrow apartheid in South Africa. ${ }^{99}$ The significance of the Bastion Point occupation in Auckland in 1978 is often revisited and has been the subject of several television documentaries. ${ }^{100}$

The Bastion Point protest had long-term outcomes for Māori and lasting impacts on New Zealand as a whole. These included the establishment in 1985 by a Labour Government of the legal right for Māori to make retrospective claims to the Waitangi Tribunal to reclaim forfeited land; the government's acceptance of the Tribunal's decision that Bastion Point was indeed Māori land; and the recommendation that twenty-two acres of land as well as houses on that land should be returned to Ngāti Whātua. The final agreement on the hand-back of Bastion Point to Ngāti Whātua was made in 1987. More recently, in 2012 a Treaty of Waitangi settlement bill, the Ngāti Whātua Orākei Claims Settlement Bill, became law. ${ }^{101}$ The settlement consisted of an apology from the Crown, an agreed historical account, and cultural and commercial remedies aimed at covering the loss of some 32,000 hectares of land on the Auckland isthmus.

In considering Herbs' song "One Brotherhood" as a song of political protest directed at these injustices, it aligns with David Laing's definition of a protest song as an overt statement of opposition to social, political, and economic conditions. ${ }^{102}$ In this case, the lyrics of the first verse openly and directly address the objects of protest in voicing protest against police treatment of demonstrators, against political authorities who move the goalposts, and against those who attempted to hide the truth of apartheid: "So you knock me down... you'd rather not know time is dealing out your days". However, while Laing describes resistance songs as more opaque or coded in their expression of opposition and criticism than protest songs, features of "One Brotherhood" resonate with Barbara Harlow's analysis of political resistance in poetry. ${ }^{103}$ According to Harlow, resistance writers have an impulse to locate their work in

\footnotetext{
${ }^{96}$ Alexandra Ganser, Julia Pühringer, and Markus Rheindorf, "Bakhtin's Chronotope on the Road: Space, Time, and Place in Road Movies since the 1970s," Linguistics and Literature 4, no. 1 (2006): 15.

${ }^{97}$ Malcolm V. Jones, Dostoyevsky after Bakhtin: Readings in Dostoyevsky's Fantastic Realism (Cambridge: Cambridge University Press, 1990), https://doi.org/10.1017/CBO9780511519604.

${ }^{98}$ For example, Fiona Rae, “Days of Rage 1981,” New Zealand Listener, July 15, 2011.

${ }_{99}$ These include a speech by the Reverend Makhenkesi Arnold Stofile cited in David Long, "SA Offers Apology to Maori Rugby," Sunday News, May 5, 2010, www.stuff.co.nz/sport/rugby/news/3673443/SA-offers-apology-to-Maori-rugby.

${ }^{100}$ Such as Morrison, Bastion Point: The Untold Story.

${ }^{101}$ See Isaac Davison, "Long-Fought Treaty Claim Settled," New Zealand Herald, November 15, 2012.

${ }^{102}$ David Laing, "Resistance and Protest," Continuum Encyclopedia of Popular Music of the World: Media, Industry and Society (New York: Continuum, 2003), retrieved from http://www.continuumbooks.com/books/detail.aspx?BookId=117086, https://doi.org/10.5040/9781501329227-0025505.

${ }^{103}$ Barbara Harlow, Resistance Literature (New York: Methuen, 1987).
} 
specific contexts and intend their texts to be read as case histories of particular lives and particular times; rather than being coded, resistance poetry is a documentary poetry that provides accounts of day to day historic struggles, events and people. On this view, resistance is similarly constructed in "One Brotherhood" in the "documentary" references to struggles in specific places for the return of Māori land, as well as through a network of dialogical relationships. In the context of recent events at that time and planned protests against the Springbok tour, these relationships include tensions and conflicts between the music, the lyrical content, and aspects of Herbs' performance, such as the harmonized, polyphonic chorus that calls for the unity of one brotherhood and sisterhood. As this analysis also suggests, the title of the song and its repetition in the chorus can be understood as a plea for a particular form of resistance, a rhetorical exhortation to resist the injustices evoked by the places named and the injustice of racism. Furthermore, at the same time as generating a sense of political and geographic identity, Herbs' appropriation and localization of Jamaican reggae as a recognized genre of social commentary is a positioning associated with critique and resistance. In addition, choices of indicators of time and space and of tense use contribute to a creatively "deformed" representation of time and space which, along with the juxtaposition of lyrical content in the two verses, has the effect of overtly connecting protest against the Springbok tour to the issue of Māori land rights. "One Brotherhood" is thus a song of protest and resistance that rhetorically connects highly political events and issues that were significant to Herbs' audiences at the time, and that have continuing significance for Aotearoa New Zealand.

\section{Bibliography}

Alvarez, Luis. "Reggae Rhythms in Dignity's Diaspora: Globalization, Indigenous Identity, and the Circulation of Cultural Struggle ." Popular Music and Society 31, no. 5 (2008): 575-97. https://doi.org/10.1080/03007760802188272.

APRAAMCOS. "Herbs." APRA AMCOS New Zealand, 2012. http://www.apraamcos.co.nz/awards/awards/silver-scroll-awards/new-zealand-music-hall offame/herbs/.

Bakhtin, Mikhail. "The Bildungsroman and Its Significance in the History of Realism (toward a Historical Typology of the Novel).” Translated by Vern W. McGee. In Speech Genres and Other Late Essays, edited by Caryl Emerson and Michael Holquist, 10-59. Austin: University of Texas Press, 1986.

_. "Discourse in the Novel." Translated by Caryl Emerson and Michael Holquist. In The Dialogic Imagination: Four Essays by M.M. Bakhtin, edited by Michael Holquist, 259-422. Austin: University of Texas Press, 1981.

- "Forms of Time and of the Chronotope in the Novel." Translated by Caryl Emerson and Michael Holquist. In The Dialogic Imagination: Four Essays by M.M. Bakhtin, edited by Michael Holquist, 84-258. Austin: University of Texas Press, 1981.

- "The Problem of Speech Genres." Translated by Vern W. McGee. In Speech Genres and Other Late Essays, edited by Caryl Emerson and Michael Holquist, 60-102. Austin: University of Texas Press, 1986.

- Problems of Dostoevsky's Poetics. Translated by Caryl Emerson. Manchester: Manchester University Press, 1984. https://doi.org/10.5749/j.ctt22727z1.

- Rabelais and His World. Translated by Helene Iswolsky. Bloomington: Indiana University Press, 1984.

Belich, James. Paradise Reforged. Auckland: Penguin, 2001.

Bloor, Meriel, and Thomas Bloor. The Practice of Critical Discourse Analysis: An Introduction. London: Hodder Arnold, 2007. 
Boyd, Margaret. "New Zealand and the Other Pacific Islands." In The Oxford Illustrated History of New Zealand, edited by Keith Sinclair, 295-322. Oxford: Oxford University Press, 1993.

Brackett, David. Interpreting Popular Music. Cambridge: Cambridge University Press, 1995.

Bradley, Lloyd Bass Culture: When Reggae Was King. London: Penguin, 2000.

Brandist, Craig. The Bakhtin Circle: Philosophy, Culture and Politics. London: Pluto Press, 2002.

Carlin, John. Playing the Enemy: Nelson Mandela and the Game That Made a Nation. London: Atlantic Books, 2008.

Cattermole, Jennifer. “'Oh, Reggae but Different!': The Localisation of Roots Reggae in Aotearoa.” In Home, Land and Sea: Situating Music in Aotearoa New Zealand, edited by Glenda Keam and Tony Mitchell, 47-59. Auckland: Pearson, 2011.

. "The Routes of Roots Reggae in Aotearoa/New Zealand: The Musical Construction of Place and Identity." Master's thesis, University of Otago, New Zealand, 2004.

Chivallon, Christine. "Beyond Gilroy's Black Atlantic: The Experience of the African Diaspora." Diaspora 11, no. 3 (2002): 359-82. https://doi.org/10.1353/dsp.2011.0055.

Daly, Michael, and Katie Kenny. “Nelson Mandela’s New Zealand Legacy.” Stuff, December 6, 2013. ] http://www.stuff.co.nz/world/africa/9485493/Nelson-Mandelas-New-Zealand-legacy.

Davison, Isaac. "Long-Fought Treaty Claim Settled." New Zealand Herald, November 15, 2012.

Dix, John. Stranded in Paradise: New Zealand Rock and Roll - 1955 to the Modern Era. Wellington, New Zealand: Penguin, 2005.

Eagleton, Terry. The Event of Literature. New Haven and London: Yale University Press, 2012. . How to Read a Poem. Oxford: Blackwell, 2007.

Fala, Tony. "A Riddim Resisting Against the System: Bob Marley in Aotearoa." PhD thesis, University of Auckland, 2008.

Fonoti, Toni. "French Letter." Herbs, French Letter. Warrior Records, 1982, vinyl record.

Ganser, Alexandra, Julia Pühringer, and Markus Rheindorf. "Bakhtin's Chronotope on the Road: Space, Time, and Place in Road Movies since the 1970s." Linguistics and Literature 4, no. 1 (2006): 1-17.

Goodman, Fraser. “My Dream 'The Creation of the Herbs Band-What's Be Happen!'” Interview with Toni Fonoti. Poly Cafe (audio blog), 2010. http://www.blogtalkradio.com/polycafe/2010/10/24/poly cafe-my-dream-the-creation-of-the-herbs-band-whats-be-happen-1.

Hall, Stuart. "Cultural Identity and Diaspora." In Identity: Community, Culture, Difference, edited by Jonathan Rutherford, 222-37. London: Lawrence and Wishart, 1990.

Harlow, Barbara. Resistance Literature. New York: Methuen, 1987.

Herbs. Light of the Pacific. Warrior Records, 1983.

-What's Be Happen?. Auckland: Warrior Records, 1981, vinyl record.

Hirschkop, Ken. "Bakhtin, Discourse and Democracy." New Left Review 1, no. 160 (1986): 92-113.

_. Mikhail Bakhtin: An Aesthetic for Democracy. Oxford: Oxford University Press, 1999. https://doi.org/10.1093/acprof:oso/9780198159612.001.0001.

Holquist, Michael. Dialogism: Bakhtin and His World. London: Routledge, 1990. https://doi.org/10.4324/9780203330340.

Hubbard, Anthony. "For a Good Cause." Sunday Star Times, August 29, 2010 , C4.

Human Rights Commission. "Race against Time.” Wellington: Race Relations Conciliator 1982.

—. "Racial Harmony in New Zealand: A Statement of Issues." Wellington, 1979.

Jones, Malcolm V. Dostoyevsky after Bakhtin: Readings in Dostoyevsky's Fantastic Realism. Cambridge: Cambridge University Press, 1990. https://doi.org/10.1017/CBO9780511519604.

King, Michael. The Penguin History of New Zealand. Auckland: Penguin, 2003.

Laing, David. "Resistance and Protest." Continuum Encyclopedia of Popular Music of the World: Media, Industry and Society. New York: Continuum, 2003. Retrieved from http://www.continuumbooks.com/books/detail.aspx?BookId=117086. https://doi.org/10.5040/9781501329227-0025505.

Lipsitz, George. Dangerous Crossroads: Popular Music, Postmodernism, and the Poetics of Place. London and New York: Verso, 1994. 
Long, David. "SA Offers Apology to Maori Rugby.” Sunday News, May 5, 2010. www.stuff.co.nz/sport/rugby/news/3673443/SA-offers-apology-to-Maori-rugby.

Minto, John. "Protest and Dissent Were Everywhere." In Glory Days: From Gumboots to Platforms, edited by Ian Chapman, 147-9. Auckland: HarperCollins, 2009.

Mita, Merata, dir. Patu! New Zealand: Awatea Films, 1983.

Mitchell, Tony. Popular Music and Local Identity: Rock, Pop and Rap in Europe and Oceania. London: Leicester University Press, 1996.

Moffatt, Glen. "Herbs History." Herbs. 2013. http://www.glenmoffatt.com/herbs history.htm.

Moore, Paddy. "Address to Local [Christchurch] Hart Branch [Transcription]." University of Canterbury Springbok Tour Archive, no. 37 (June 1981): 292-97. http://digitallibrary.canterbury.ac.nz/data/library3/archives/113561.pdf.

Morrison, Bruce, dir. Bastion Point: The Untold Story. New Zealand: Morrison Grieve and Moko Productions, 1999.

Nielsen, Greg. "Bakhtin and Habermas: Toward a Transcultural Ethics ." Theory and Society 24, no. 6 (1995): 803-35. https://doi.org/10.1007/BF00994066.

Orakei Maori Committee Action Group. Takaparawha Bastion Point : 506 Days on Ancestral Maori Land: Bastion Point Defenders Reply to Government and Justice Speight. Auckland: Orakei Maori Committee Action Group, 1978.

Rae, Fiona. "Days of Rage 1981.” New Zealand Listener, July 15, 2011.

Reid, Graham. "Herbs, New Zealand's Politicised Reggae Revolution: Hard Tings an' Times." Elsewhere, September 2, 2012. http://www.elsewhere.co.nz/absoluteelsewhere/2753/herbs-new zealandspoliticised-reggae-revolution-hard-tings-an-times/.

Reid, Zoe. "How the Polynesian Panthers Changed Our World." Salient, May 31, 2010. http://salient.org.nz/2010/05/how-the-polynesian-panthers-changed-our-world/.

Ryan, Kathryn. "Feature Guest-Dilworth Karaka." Nine to Noon, Radio New Zealand, December 24, 2012.

"Search for harmony." New Zealand Herald, April 10, 1980.

Sinclair, Keith. A History of New Zealand. Auckland Penguin, 1988.

Toms, Phil. "One Brotherhood.” Herbs, What's Be Happen? Warrior Records, 1981, vinyl record.

Tourell, Wayne "Land of a Thousand Lovers (Tv Documentary)." In Perspective. New Zealand, 1977.

Turner, Elizabeth. "What's Be Happen? A Dialogical Approach to the Analysis of Herbs' New Zealand Reggae Lyrics." Knowledge Cultures 3, no. 4 (2015): 91-115.

Voloshinov, Valentin Nikolaevich. Marxism and the Philosophy of Language. Translated by Ladislav Matejka and I.R. Titunik. Cambridge, MA: Harvard University Press, 1986.

Walker, Ranginui. Ke Whawhai Tonu Matou: Struggle without End, 2nd ed. Auckland: Penguin, 2004.

Waring, Marilyn. "A Feminist Perspective." In Glory Days: From Gumboots to Platforms, edited by Ian Chapman, 155-8. Auckland: HarperCollins, 2009.

Weber, Thomas J. "Likkle but Talawah (Small but Mighty): Reggae Music, Globalization, and the Birth of a Social Movement." PhD diss., Bowling Green State University, 2000.

Williams, Joe. "The Future of Maori Resource Management." Beyond the RMA: An In-Depth Exploration of the Resource Management Act 1991. Conference Proceedings, 59-65. Auckland: Environmental Defence Society, 2007. 